\title{
Studies on the extended spectrum beta lactamases activity in isolates from diabetes patients
}

\author{
AL Dorothy Kalyani ${ }^{1,2^{*}}$, T Palaniappan $^{1}$, V Mohan $^{1}$, T Sundararaj $^{3}$ \\ From First International Science Symposium on HIV and Infectious Diseases (HIV SCIENCE 2012) \\ Chennai, India. 20-22 January 2012
}

\section{Background}

Extended spectrum beta-lactamases (ESBLs) are enzymes produced by some gram negative bacilli that mediate resistance to extended-spectrum cephalosporins and aztreonam. ESBLs are commonly recognized in a variety of Enterobacteriaceae and Pseudomonas aeruginosa isolates. This study focused on the prevalence of ESBL producing strains from diabetes patients and their antimicrobial correlation.

\section{Methods}

ESBL activity studied in different gram negative bacteria isolated from $\mathrm{xxx}$ urine samples were subjected to antimicrobial susceptibility testing by Kirby-Bauer method as per CLSI guidelines antimicrobials agents (Cefpodoxime, Ceftazidime, Cefotaxime, \& Ceftriaxone) selected for testing along with combinations of antimicrobials Cefoperazone sulbactam (CFS), Piperacillin-tazobactam (PT) Amoxyclav (AC) were compared for their ability to detect ESBL producers phenotypically.

\section{Results}

Among 4446 samples processed 3426 showed ESBL activity in different gram negative bacilli $85 \%$ in E.coli, 7\% Klebsiella pneumoniae, 0.5\% Klebsiella oxytoca, 2.3\% Pseudomonas aeruginosa, 0 .5\% Citrobacter koseri, 1\% in Proteus mirabilis.

\section{Conclusion}

There is a significant increase in the prevalence of ESBL E.coli when compared to other gram negative isolates. Detection of ESBL by phenotypic method in the absence

\footnotetext{
* Correspondence: aldorothykalyani@gmail.com

'Dr. Mohan's Diabetes Specialities Centre, Gopalapuram, Chennai, India

Full list of author information is available at the end of the article
}

of molecular testing is considered as timely, affordable and appropriate measure in deciding the antibiotic therapy.

\section{Author details}

${ }^{1}$ Dr. Mohan's Diabetes Specialities Centre, Gopalapuram, Chennai, India. ${ }^{2}$ Meenakshi Ammal Dental College, Maduravoyal, Chennai, India. ${ }^{3}$ Jasmn Laboratory, Jasmn Education \& Research Foundation, Perungudi, Chennai, India.

Published: 4 May 2012

\section{doi:10.1186/1471-2334-12-S1-P86}

Cite this article as: Kalyani et al:: Studies on the extended spectrum beta lactamases activity in isolates from diabetes patients. BMC Infectious Diseases 2012 12(Suppl 1):P86.
Submit your next manuscript to BioMed Central and take full advantage of:

- Convenient online submission

- Thorough peer review

- No space constraints or color figure charges

- Immediate publication on acceptance

- Inclusion in PubMed, CAS, Scopus and Google Scholar

- Research which is freely available for redistribution

Submit your manuscript at www.biomedcentral.com/submit

\section{() Biomed Central}

C 2012 Kalyani et al; licensee BioMed Central Ltd. This is an Open Access article distributed under the terms of the Creative Commons Attribution License (http://creativecommons.org/licenses/by/2.0), which permits unrestricted use, distribution, and reproduction in any medium, provided the original work is properly cited. 